\title{
PENGARUH PENDEKATAN MATEMATIKA REALISTIK (PMR) TERHADAP KEMAMPUAN PEMECAHAN MASALAH MATEMATIKA SISWA KELAS VIII MTs AL AZHAR BULU CINA TAHUN PELAJARAN 2017/2018
}

\author{
Sucia Asri Andini ${ }^{1}$ \\ Silvia Harleni ${ }^{2}$ \\ STKIP Budidaya Binjai \\ Syl_nst@yahoo.com
}

\begin{abstract}
Abstrak
Penelitian ini bertujuan untuk mengetahui pengaruh pendekatan matematika realistik (PMR) terhadap kemampuan pemecahan masalah matematika siswa. Populasi penelitian ini adalah siswa kelas VIII MTs Al-Azhar Bulu Cina tahun pelajaran 2017/2018 yang berjumlah 91 orang. Secara acak, dipilih dua kelas sebagai subyek penelitian. Kelas eksperimen diberi pendekatan matematika realistik dengan jumlah 31 orang dan kelas kontrol diberi metode konvensional yang berjumlah 30 orang. Instrumen yang digunakan dalam penelitian ini berupa: tes kemampuan pemecahan masalah. Instrumen tersebut dinyatakan telah memenuhi syarat validitas serta koefisien reliabilitas untuk kemampuan pemecahan masalah matematika. Hasil utama dari penelitian ini adalah : secara keseluruhan siswa yang menggunakan pendekatan matematika realistik secara signifikan rata-rata pengaruh kemampuan pemecahan masalah matematikanya lebih baik daripada rata-rata kemampuan pemecahan masalah matematika siswa yang menggunakan metode konvensional. Berdasarkan hasil penelitian maka pendekatan matematika realistik dapat memberikan pengaruh terhadap kemampuan pemecahan masalah matematika siswa. Peneliti menyarankan agar pendekatan matematika realistik bisa diterapkan pada pembelajaran matematika untuk dijadikan sebagai salah satu alternatif dalam menerapkan pembelajaran matematika yang inovatif, dapat menciptakan suasana pembelajaran yang menyenangkan, serta memberi kesempatan pada siswa untuk mengungkapkan gagasannya dalam bahasa dan cara yang baik.
\end{abstract}

Kata kunci : Pendekatan Matematika Realistik (PMR), Kemampuan Pemecahan Masalah Matematika, Metode Konvensional.

\section{A. PENDAHULUAN}

Matematika merupakan ilmu pengetahuan yang penting, maka penerapannya sangat dibutuhkan guna kemajuan dalam bidang pendidikan. Hujodo (2005) menyatakan bahwa matematika adalah suatu alat mengembangkan cara berfikir. Karena itu matematika diperlukan untuk kehidupan sehari-hari maupun dalam menghadapi kemajuan IPTEK sehingga matematika perlu dibekalkan kepada setiap peserta didik sejak SD, bahkan sejak TK. Tetapi banyak siswa yang menganggap matematika sebagai pelajaran yang sulit dan susah dimengerti. Bahkan ada yang menganggap pelajaran matematika sebagai pelajaran yang tidak ada kaitannya dengan kehidupan. Kebiasaan berfikir seperti ini yang seharusnya diubah mengingat begitu banyak manfaat yang didapat dari pembelajaran matematika.

Dalam pemecahan masalah matematika dibutuhkan analisa yang tepat. Contohnya dalam menyelesaikan soal berbentuk cerita. Sebelum mencari pemecahan masalahnya mereka diharuskan 
untuk mengetahui kemana arah penyelesaian dari soal tersebut. Melalui wawancara, pengamatan dan tes awal yang telah dilakukan oleh peneliti di sekolah MTs Al-Azhar Bulu Cina terlihat bahwa siswa di sekolah tersebut masih banyak yang menganggap matematika sebagai pelajaran yang sulit dan susah dipahami.

Dari tes kemampuan awal yang dilakukan oleh peneliti di sekolah MTs AlAzhar Bulu Cina menunjukkan bahwa kemampuan pemecahan masalah siswa masih tergolong kurang tepat. Dari 10 orang siswa yang mengikuti tes awal hanya ada 3 orang siswa yang menjawab dengan benar dan 7 siswa menjawab salah. Hal ini menunjukkan bahwa kemampuan pemecahan masalah siswa masih tergolong rendah.

Maka dari itu diperlukan suatu model dan strategi pendekatan yang lebih realistik sehingga dalam menyelesaikan masalah, siswa bisa mencari penyelesaian melalui pengamatan di lingkungan sekitarnya. Karena soal yang berkaitan dengan kemampuan pemecahan masalah, sebagian besar berbentuk soal cerita yang pengaplikasiannya sangat dekat sekali dengan realita kehidupan siswa.

Penggunaan metode mengajar dan strategi pendekatan oleh guru sangat menentukan kegiatan belajar siswa, serta penggunaan alat peraga yang ada dapat menunjang proses pembelajaran matematika. Terkadang suasana pengajaran di sekolah yang digunakan para guru, tampaknya lebih menghambat dalam memotivasi potensi otak. Misalnya, seorang siswa hanya disiapkan sebagai seorang anak yang mau mendengarkan, mau menerima seluruh informasi, dan menaati segala perlakuan gurunya. Budaya dan mental yang seperti ini, pada gilirannya membuat siswa tidak mampu mengaktivasi kemampuan otaknya sehingga mereka tidak memiliki keberanian menyampaikan pendapat, lemah penalaran, dan bergantung kepada orang lain. Menurut Indar Djati Sidi dalam Hamdani (2011) menyatakan bahwa budaya mental yang seperti ini akan berdampak pada budaya mental masyarakat secara luas, yaitu masyarakat yang belum bisa berpikir secara mandiri, walaupun belum bisa dipastikan budaya yang seperti ini bemula dari sekolah atau justru sekolah dipengaruhi masyarakat luar. Akan tetapi semuanya saling mendukung untuk menyuburkan budaya tersebut. Cara belajar seperti ini tidak efektif karena kelas hanya diisi dengan pembelajaran yang terpusat pada guru. Untuk mengatasi hal ini maka dibutuhkan strategi dan pendekatan yang sesuai agar tujuan pembelajaran matematika dapat tercapai.

Oleh karena itu masih diperlukan upaya dalam meningkatkan kemampuan pemecahan masalah matematika siswa, diantaranya dengan menerapkan pendekatan yang sesuai denggan nilai kriteria ketuntasan minimal yang dengan penerapannya diharapkan akan meningkatkan kemampuan pemecahan masalah matematika siswa. Dalam hal ini Pendekatan Matematika Realistik (PMR) dirasa tepat untuk mengatasi kesulitan pemecahan masalah karena pada dasarnya pendekatan matematika realistik adalah pemanfaatan realitas dan lingkungan yang dipahami siswa untuk memperlancar proses pembelajaran matematika sehingga mencapai tujuan pendidikan matematika secara lebih baik dari pada yang lalu. 
Berdasarkan masalah di atas, maka perlu diadakan penelitian untuk mengetahui apakah pembelajaran matematika dengan pendekatan matematika realistik (PMR) efektif diterapkan sehingga peneliti tertarik untuk mengadakan penelitian dengan judul : Pengaruh Pendekatan Matematika Realistik (PMR) terhadap Kemampuan Pemecahan Masalah Matematika Siswa Kelas VIII MTs Al Azhar Bulu Cina Tahun Pelajaran 2017/2018.

\section{Pendekatan Matematika Realistik (PMR)}

Pendekatan matematika realistik adalah suatu pendekatan belajar matematika yang dikembangkan sejak tahun 1971 oleh sekelompok ahli matematika dari Freudenthal Institute, Utrecht University di negeri Belanda. Pembelajaran mtematika realistik merupakan operasionalisasi dari suatu pendekatan matematika yang pada dasarnya adalah pemanfaatan realitas dan lingkungan yang di pahami peserta didik untuk memperlancar proses pembelajaran matematika, sehingga mencapai tujuan pendidikan matematika secara lebih baik dari pada yang lalu.

Pendekatan matematika realistik adalah salah satu teori pembelajaran yang dikembangkan khusus untuk matematika. Dalam pendekatan matematika realistik pembelajaran dimulai dari sesuatu yang real sehingga siswa dapat terlibat dalam proses pembelajaran secara bermakna dalam proses tersebut peran guru hanya sebagai fasilitator bagi siswa dalam proses rekonstruksi ide dan konsep matematika (Susana, et. al, 2014).
Dickinson P (dalam Wijayanti, 2016) menyatakan bahwa pendekatan matematika realistik menunjukkan hasil yang berbeda daripada metode solusi lainnya dikarenakan pendekatan matematika realistik menggunakan konteks yang tidak hanya ilustrasi melainkan menggunakan model konteks dari dunia nyata, pendekatan matematika realistik menggunakan model dari konteks seperti gambar kemudian dipresentasikan dalam bentuk garis, rasio, tabel, dan sebagainya, konteks dalam pendekatan matematika realistik dipilih untuk mengembangkan berbagai strategi yang berbeda dan siswa selalu merefleksikan secara konstan.

\section{Kemampuan Pemecahan Masalah Matematika}

Penelitian tentang pemecahan masalah telah banyak dilakukan. Harleni dan susilawati (2018) meneliti tentang efektifitas penggunaan model problem based learning terhadap kemampuan pemecahan program linear dengan memamfaatkan software QM pada mahasiswa STKIP Budidaya Binjai. Saputri (2018) meneliti tentang pengaruh model pembelajaran kooperatif tipe jigsaw terhadap kemampuan pemecahan masalah matematika siswa SMP Swasta Swadaya Batang Serangan. Masalah matematika adalah kecakapan atau potensi yang dimiliki seseorang atau peserta didik dalam menyelesaikan soal cerita, sebagai suatu usaha mencari jalan keluar dari suatu kesulitan guna mencapai suatu tujuan. Pemecahan masalah sebagai salah satu aspek kemampuan berfikir tingkat tinggi. Polya (dalam Aini, 2017) menyatakan bahwa pemecahan masalah merupakan 
suatu tingkat aktivitas intelektual yang sangat tinggi. Kemampuan pemecahan masalah merupakan tujuan umum dalam pembelajaran matematika, bahkan sebagai jantungnya matematika, artinya kemampuan pemecahan masalah merupakan kemampuan dasar dalam matematika.

Pemecahan masalah dianggap merupakan standar kemampuan yang harus dimiliki para siswa setelah menyelesaikan pembelajaran. Yamin (2008) menyatakan bahwa pemecahan masalah adalah strategi yang merangsang berfikir dan menggunakan wawasan tanpa melihat kualitas pendapat yang disampaikan peserta didik. Beberapa indikator kemampuan pemecahan masalah matematika yang dikemukakan oleh Sumarmo (dalam Aini, 2017) :

1. Memahami masalah, yaitu mengidentifikasi kecukupan data untuk menyelesaikan masalah, sehingga memperoleh gambaran lengkap apa yang diketahui dan dinyatakan dalam masalah tersebut.

2. Merencanakan penyelesaian, yaitu menetapkan langkah-langkah penyelesaian, pemilihan konsep, persamaan dan teori yang sesuai untuk setiap langkah.

3. Menjalankan rencana, yaitu menjalankan penyelesaian berdasarkan langkah-langkah yang telah dirancang dengan menggunakan konsep, persamaan serta teori yang dipilih.

4. Melihat kembali apa yang telah dikerjakan, yaitu tahap pemeriksaan, apakah langkah-langkah penyelesaian telah terealisasikan sehingga dapat memeriksa kembali kebenaran jawaban yang pada akhirnya membuat kesimpulan akhir.

\section{B. METODE PENELITIAN}

Populasi dalam penelitian ini adalah siswa kelas VIII MTs Al Azhar Bulu Cina tahun pelajaran 2017/2018, terdiri dari 3 kelas dengan jumlah 91 orang. Jenis penelitian yang digunakan dalam penelitian ini adalah eksperimen semu (quasi experimental). Dalam penelitian ini, peneliti mengumpulkan data dengan memberikan perlakuan yang berbeda pada kedua kelompok sampel penelitian. Subjek penelitian akan diberikan perlakuan kepada dua kelompok yaitu kelompok eksperimen dan kelompok kontrol, kemudian akan dianalisis pengaruh dari perlakuan yang diberikan.

Perlakuan yang diberikan yaitu pembelajaran matematika dengan menggunakan Pendekatan Matematika Realistik (PMR). Penelitian dilakukan untuk melihat pengaruh Pendekatan Matematika Realistik (PMR) terhadap kemampuan pemecahan masalah matematika siswa kelas VIII MTs Al Azhar Bulu Cina Tahun Pelajaran 2017/2018. Variabel dalam penelitian ini adalah variabel bebas yaitu Pendekatan Matematika Realistik (PMR) dan variabel terikat yaitu kemampuan pemecahan masalah matematika siswa.

\section{HASIL PENELITIAN}

Setelah data hasil pretest dan posttest terpenuhi untuk uji normalitas dan uji homogenitas, maka dilakukan analisis regresi sederhana. Dari hasil perhitungan diperoleh model regresi sebagai berikut:

$$
\bar{Y}=67,85+0,75 X
$$


Sebelum analisis regresi digunakan maka diperlukan uji keberartian dan uji linieritas terlebih dahulu. Hasil uji keberartian dan uji linieritas disajikan pada daftar analisis varians (ANAVA) regresi linier sederhana.

Tabel 1.

Hasil Perhitungan Keberartian

Koefisien Regresi Pada Kelas

Eksperimen

\begin{tabular}{llllll}
\hline \multicolumn{1}{c}{ Varians } & \multicolumn{1}{c}{ JK } & Db & \multicolumn{1}{c}{ RJK } & $\mathbf{F}_{\text {hitung }}$ & $\mathbf{F}_{\text {tabel }}$ \\
\hline \multicolumn{1}{c}{ Total } & 111179 & 31 & & & \\
Regresi(a) & 106659,59 & 1 & & & \\
Regresi(b/a) & 1945,40 & 1 & 1945,40 & 18,9 & 4,24 \\
Sisa & 2574 & 30 & 103 & & \\
Kekeliruan & 2366,9 & 4 & 9,9 & & \\
Tuna Cocok & 207,1 & 19 & 591,7 & 0,017 & 5,79 \\
\hline
\end{tabular}

Pada tabel 1 tersebut menunjukkan harga $F_{\text {tabel }}$ diperoleh dengan melihat daftar distribusi F dengan taraf nyata 5\% . Dengan demikian dapat dilihat bahwa $\mathrm{d}_{\text {pembilang }}=21$ dan $\mathrm{dk}_{\text {penyebut }}=4$ sehingga $\mathrm{F}_{\text {hitung }}<\mathrm{F}_{\text {tabel }}$ yaitu $0,017<5,79$ berarti $\mathrm{H}_{0}$ diterima sehingga regresi $\mathrm{Y}$ atas $\mathrm{X}$ linier

Hipotesis yang akan diuji adalah :

$$
\begin{aligned}
& \mathrm{H}_{0}: \theta_{1}=\theta_{2} \\
& \mathrm{Ha}: \theta_{1} \neq \theta_{2}
\end{aligned}
$$

Hipotesis yang diujikan :

$\mathrm{H}_{0}=$ Tidak terdapat pengaruh Pendekatan

Matematika Realistik terhadap kemampuan pemecahan masalah matematika siswa kelas VIII MTs Al-Azhar Bulu Cina tahun pelajaran 2017/2018.

H1=Terdapat pengaruh Pendekatan Matematika Realistik terhadap kemampuan pemecahan masalah matematika siswa kelas VIII MTs
Al-Azhar Bulu Cina tahun pelajaran 2017/2018.

Tabel 2.

Hasil Uji Hipotesis

\begin{tabular}{ccc}
\hline $\mathbf{r}_{\text {hitung }}$ & $\mathbf{r}_{\text {tabel }}$ & $\mathbf{n}$ \\
\hline 5,771 & 1,708 & 27 \\
\hline
\end{tabular}

Setelah dilakukan perhitungan dengan menggunakan uji-t, maka diperoleh $t_{\text {hitung }}=5,771$. Kemudian nilai tersebut dibandingkan dengan $t_{\text {tabel }}=$ 1,708 dengan $\mathrm{n}=31$ dan taraf signifikan $5 \%$. Karena $t_{\text {hitung }}>t_{\text {tabel }}$ maka $\mathrm{H}_{0}$ ditolak dan $\mathrm{H}_{\mathrm{a}}$ diterima, dengan demikian dapat disimpulkan terdapat pengaruh antara pendekatan matematika realistik dan kemampuan pemecahan masalah matematika siswa.

\section{D.KESIMPULAN}

Berdasarkan analisis data dan pembahasan maka diperoleh bahwa $\mathrm{H}_{0}$ ditolak dan $\mathrm{H}_{\mathrm{a}}$ diterima sehingga arah koefisen cukup berarti, uji kelinieritas $\mathrm{H}_{0}$ diterima dan $\mathrm{H}_{\mathrm{a}}$ ditolak maka linier, dan uji hipotesis $\mathrm{H}_{0}$ ditolak dan $\mathrm{H}_{\mathrm{a}}$ diterima. Sehingga dapat disimpulkan bahwa Pendekatan Matematika Realistik (PMR) dapat memberikan pengaruh terhadap hasil kemampuan pemecahan masalah matematika siswa yang lebih tinggi dibandingkan dengan pembelajaran yang menerapkan metode konvensional pada siswa kelas VIII MTs Al-Azhar Bulu Cina tahun pelajaran 2076/2018. 


\section{DAFTAR PUSTAKA}

Aini, Kurratul. Penerapan Pendidikan Matematika Realistik (PMR) dalam Meningkatkan Kemampuan Pemecahan Masalah Matematika Siswa Sekolah Dasar. 1(1) 2017.

Hamdani, Dr. Strategi Belajar Mengajar. Bandung : Pustaka Setia. 2011.

Harleni, Silvia dan Susilawati, Enny. Efektifitas Penggunaan Model Problem Based Learning Terhadap Kemampuan Pemecahan Program Linear Dengan Memamfaatkan Software QM Pada Mahasiswa STKIP Budidaya Binjai. Binjai: STKIP Budidaya Binjai. 2018.

Hujodo, Herman. Pengenbangan Kurikulum Dan Pembelajaran Matematika. Malang: UM Press, 2005.

Saputri, Lilis. Pengaruh Model Pembelajaran Kooperatif Tipe
Jigsaw Terhadap Kemampuan Pemecahan Masalah Matematika Siswa SMP Swasta Swadaya Batang Serangan. Binjai: STKIP Budidaya Binjai. 2018.

Susana, Devi dkk. Penerapan Pendekatan Matematika Realistik (PMR) terhadap Kemampuan Pemecahan Masalah Matematika Siswa SMP Negeri 1 Sungai Penuh. 1(1) 2014.

Wijayanti, Septiana. Penggunaan Pendekatan Realistic Mathematic Education (RME) sebagai Upaya Peningkatan Kreativitas dalam Pemecahan Masalah Matematika Siswa Kelas X7 SMA Negeri 1 Pulokulon. 28 maret 2016.

Yamin, Martinis. Strategi dan Metode dalam Model Pembelajaran. Jakarta: Media Prenada, 2008. 